\title{
治験参加者を対象とした治験に関する意識変化を 定量的に解析した研究
}

\author{
小嶋悪 純* 山崎晶 司* 吉尾卓*
}

\author{
Quantitative Analysis of Perception Changes in Clinical Trial Participants During Clinical Trials \\ Asumi KOJIMA*, Shoji YAMAZAKI* and Taku YOSHIO* \\ * Department of Clinical Trial Promotion, Jichi Medical University Hospital, Japan
}

Background: Many surveys on perception changes in clinical trial participants have been conducted. However, these surveys have provided only qualitative evaluations of the impressions in participating in clinical trials. The degree of perception changes in participants during clinical trials and the factors that contribute to perception changes remain unclear.

Objective: Understanding the perceptions of participants is extremely important to promote clinical trials. The aims of this study were to clarify quantitatively the degree of perception changes in participants during clinical trials and to identify the factors contributing to the changes.

Methods: We surveyed perception changes in the same participants before and after clinical trials. The degree of anxiety towards clinical trials was determined using the Visual Analog Scale(VAS). The factors contributing to perception changes in participants were also analyzed.

Results: Participants expected positive therapeutic effects, but also had a vague sense of anxiety prior to clinical trials. The mean VAS score for anxiety was $46.7 \mathrm{~mm}$ before clinical trials and decreased significantly to $38.0 \mathrm{~mm}$ after clinical trial $(P=0.002)$. Factors that contributed to perception changes by participants included the effectiveness of the investigational drug for individual trial participant and constraint of clinical trial schedule. In addition, the management of clinical research coordinators (CRC) was highly evaluated by participants.

Conclusion: These results suggested that CRC should contribute to the promotion of clinical trials by supporting participants who feel anxious and proposing treatment methods that reduce burden on participants to clinical trial sponsors.

Key words : perception change, degree of anxiety, quantitative questionnaire, VAS, clinical research coordinator Jpn J Clin Pharmacol Ther. 2017; 48(2): 41-49

\section{緒 論}

社会一般の治験に対する認知度は徐々に高まっている が, 多くの人にとって未だ馴染みが薄く，治験に対する漠 然とした負の印象が残存している ${ }^{1 \sim 6)}$.

当院では過去に治験参加患者（以下，「被験者」）を対象 とした定性的な意識調査を行い, これら被験者が治験に対 して抱く印象を明らかにしてきた11)。これと同様の意識調 查は過去にも幾つか行われており, 被験者は治験を経験す ることによりその理解を深め, 好意的な印象を抱くことが 報告されている ${ }^{1 \sim 3,6)}$. しかし, これらの報告は治験参加後 の一般的な感想を把握しただけに過ぎず，被験者が治験参 加前に抱く心証, 治験参加中の意識変化およびそれに影響 を及ぼした要因については明らかにされていない.
治験は被験者となり得る患者の理解と協力がなければ成 り立たず，これを推進するためには被験者に内在する多様 な意識を把握することは極めて重要である。今回, 我々は 被験者の治験に関する意識を定量的に測定し, その変化の 有無とこれに影響を与えた要因を明らかにする目的で, 前 方視的臨床研究を行った。

\section{研 究方法}

\section{1. 対 象}

2011 年 6 月から 2014 年 3 月までの間に自治医科大学附 属病院において医薬品の治験（以下,「治験」）に参加した 被験者またはその代諾者（被験者本人が未成年の場合）を 対象とした。なお，当院では健常人を対象とした治験は実 施しておらず，全ての対象者が何らかの疾患を有した患者

\section{* 自治医科大学附属病院とちぎ臨床試験推進部}

著者連絡先: 小嶋亜純 自治医科大学附属病院とちぎ臨床試験推進部 † 329-0498 下野市薬師寺 3311-1 E-mail : kojima1223@jichi.ac.jp 投稿受付 2016 年 11 月 10 日，第 2 稿受付 2016 年 12 月 28 日，第 3 稿受付 2017 年 1 月 6 日，掲載決定 2017 年 1 月 10 日 
【質問1】治験に参加される以前に、「治験」についてご存じでしたか？ (1) (3)のうち、あてはまるものひとつに○をつけてください。

(1)言葉だけでなく、その内容も知っていた

(2)言葉は聞いたことがあるけれど、内容は知らなかった

(3)言葉自体を聞いたことがなく、内容も知らなかった

【質問2】治験に参加される以前に、治験を行わなければ新薬が誕生しないことを ご存じでしたか?いずれかあてはまるものに○をつけてください。

(1)知っていた (2)知らなかった

【質問3】今回参加される治験のことを知ったきっかけは何ですか？ あてはまるもの全てに○をつけてください。

(1)担当医師から淀院内の職員 (医師以外)から

(3)病院内のポスター (4)新聞、折り込みチラシ

(5)インターネット（6)その他(具体的に：）

【質問4】今回の治験への参加を決めた動機についてうかがいます。

a) (1) (14の中で、参加の動機になった理由に、いくつでも○をつけてください。

(1)治験薬の効果を期待するから

(2)最新治療が受けられるから

(3)詳しい検査が受けられるから

(4)医師に詳しく診察してもらえるから

(5)病気.(治療)に対して前向きになりたいから

(6)病気 (治療)に関する知識をつけたいから

(7)医療費の負担が軽減するから

8)負担軽減費(参加協力費7000円)がもらえるから

(9)新薬開発·医学の進歩に貢献できるから

(10担当医師が勧めたから

(11)家族や友人が勧めたから

(12)説明文書を読んで

(13)自分で治験や薬について調べて

(14) その他 (具体的に

b) 上記a)で○をつけた中で、参加の決め手となった最大の理由をひとつだけ記入 してください。

最大の理由ひとつ: (

)〔番号を記入してください
【質問5】あなたは「治験」に対しどのような印象をお持ちですか?以下の項目ごとに あてはまる箇所に、印をつけてください

\begin{tabular}{|c|c|c|c|c|c|}
\hline 治験に対する印象は？ & $\begin{array}{l}\text { 強 } \\
\text { 思 } \\
\text { 恶 }\end{array}$ & $\begin{array}{l}\text { 少 } \\
\text { 思 } \\
\text { j }\end{array}$ & $\begin{array}{l}\text { 㜔 } \\
\text { 占 } \\
\text { な } \\
\text { い } \\
\end{array}$ & $\begin{array}{l}\text { 思あ } \\
\text { わ路 } \\
\text { な } \\
\text { いり }\end{array}$ & $\begin{array}{l}\text { 思 } \\
\text { お全 } \\
\text { な } \\
\text { 心 }\end{array}$ \\
\hline 副作用が心配である & $\square$ & $\square$ & $\square$ & $\square$ & $\square$ \\
\hline 面倒・厄介なことである & $\square$ & $\square$ & $\square$ & $\square$ & $\square$ \\
\hline 人体実験である & $\square$ & $\square$ & $\square$ & $\square$ & $\square$ \\
\hline 最新治療が受けられる & $\square$ & $\square$ & $\square$ & $\square$ & $\square$ \\
\hline 治療費が安くなる & $\square$ & $\square$ & $\square$ & $\square$ & $\square$ \\
\hline 社会貢献ができる & $\square$ & $\square$ & $\square$ & $\square$ & $\square$ \\
\hline 新薬誕生に必要である & $\square$ & $\square$ & $\square$ & $\square$ & $\square$ \\
\hline 実態がよくわからない & $\square$ & $\square$ & $\square$ & $\square$ & $\square$ \\
\hline 自分には関係ないことである & $\square$ & $\square$ & $\square$ & $\square$ & $\square$ \\
\hline
\end{tabular}

【質問6】治験」に対して、あなたはどのくらい不安を感じますか? 全く不安を感じな い状態を0、すごく不安を感じる状態を100として、下線上に「/」を記入し現在の不安 の大きさを示してください。

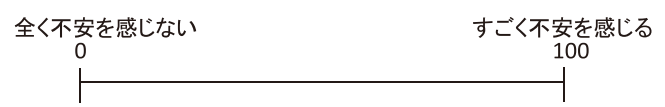

【質問7】その他、ご意見·ご要望等ございましたら、ご記入ください。

【質問8】最後に、集計上、以下の質問にお答えください。

性別 (1)男性 (2)女性年齢 ( ) 歳

Figure 1 事前調査に用いた質問票

であった。また，本研究は治験参加前後における被験者意 識の変化量を主要評価項目と設定したため，過去に治験に 参加したことがある患者あるいは重度の認知症等により研 究の実施が困難であると研究者が判断した患者は除外し た。

\section{2. 方 法}

調査は同一被験者に対し 2 回の無記名自記式アンケート (以下,「質問票」) により行った. 第 1 回目の質問票 (以下, 「事前調査」）は治験参加の同意取得時から治験薬投与開始 までの期間に実施し, 第 2 回目の質問票(以下,「事後調査」) は，治験薬投薬開始 6 力月後あるいは治験参加中止時また は終了時のいずれか早い時点に実施した。いずれの質問票 も当該被験者を担当する治験コーディネーター (Clinical Research Coordinator ; 以下, 「CRC」) が返信用封筒と共に手 交した。その際，(1)質問票への回答は任意であること，(2) 治験自体の同意とは関連がないこと,を文書により説明し， 被験者からの質問票の返送を以て本研究への参加同意とし た。

質問票は無記名としたが，同一被験者における事前調査 と事後調査の結果を比較するため, 予め質問票に管理番号 を付し, 被験者と連結可能な対応表を作成した。対応表は
研究責任者とその補助者のみが管理し, 各々の質問票を マッチングした後に破衰して連結不可能匿名化とした。

\section{3. 調査項目}

調査に用いた質問票を Figure 1 および Figure 2 に示す. 主要評価項目は,「治験に対する不安度」とし, 不安 VAS （Visual Analog Scale）を指標とした.「全く不安を感じない」 を 0 ,「すごく不安を感じる」を 100 とし, 事前調査および 事後調査の不安 VAS から変化量を算出した。

副次的評価項目は,「治験に対する印象変化 (9 項目)」と し， 5 段階評価（強く思う，少し思う，どちらとも言えな い，あまり思わない，全く思わない）の選択肢を設け，事 前調査および事後調查の印象度を比較した。 それ以外の項 目は，過去に行われた同様の意識調査 ${ }^{1)}$ を参考に質問項目 を設定した。

\section{4. 解析方法}

\section{1. 解析対象集団}

主要評価項目の解析は臨床研究実施計画書に適合した集 団 (Per Protocol Set) で行い, これ以外の項目の解析は最大 解析対象集団 (Full Analysis Set) とした. 
【質問1】あなたが治験に参加して良かったと思うことについてうかがいます。 a) (1)〜12の中で、あなたが良かったと思うことに、いくつでも○をつけてください。

(1)治験薬の効果が得られた

(3)詳しい検査が受けられた

(5)病気 (治療)に関する知識が増えた

(7)負担軽減費 (参加協力費7000円) がもらえた

(9)治験担当医師の対応

(11)その他の病院職員の対応

b) 上記a)で○をつけた中で、最も良かったと思うことをひとつだけ記入してください。 最も良かったことひとつ:( ) 世番号を記入してください

【質問2】あなたが治験に参加して悪かったと思うことについてうかがいます。 a) (1)〜112)の中で、あなたが悪かったと思うことに、いくつでも○をつけてください。

(1)治験薬の効果が得られなかった (3)治験中に使ってはいけない薬があった (5)検査の回数が多かった

(7)来院時にたくさん質問されたり

報告しなければならなかった

(9)治験担当医師の対応

(11)その他の病院職員の対応

(2)最新治療が受けられた

(4)病気 (治療)に対して前向きになれた

(6)医療費の負担が軽減した

8)新薬開発·医学の進歩に貢献できた

(10治験コーディネーターの対応

(12)その他(具体的に:

b) 上記a)で○をつけた中で、最悪かったと思うことをひとつだけ記入してください。 最も悪かったことひとつ:( ) 番号を記入してください

太治験開始後のあなたのお気持ちについてうかがいます。

【質問3】治験参加前と比べて、あなたの「不安な気持ち」に変化がありますか?

$\begin{array}{ll}\text { (1)不安は増した } & \rightarrow \text { 【質問4】へお進みください } \\ \text { (2)不安は減った } & \rightarrow \text { 【質問4】へお進みください } \\ \text { (3)変わらない } & \rightarrow \text { 【質問5】へお進みください } \\ \text { (4)参加前から不安はなかった } & \rightarrow \text { 【質問5】へお進みください }\end{array}$

太次の質問は【質問3】で(1)または(2)と回答された方にうかがいます。 【質問4】質問3】で答えた気持ちの変化に最も影響を与えたと思われることを (1)〜8)の中からひとつだけ選んで○をつけてください。

(1)病状の変化

(3)副作用や好ましくない症状の発現

(2)治験薬の効果

(5)治験コーディネーターの対応

(4)治験担当医師の対応

(6)その他の病院職員の対応

(7)家族や友人の意見 (8)その他 (具体的に:
ネここからはすべての方にうかがいます。

【質問5】あなたは「治験」に対しどのような印象をお持ちですか？以下の項目ごとに あてはまる箇所に、印をつけてください。(図は事前調査【質問5】と同一のため略)

【質問6】治験」に対して、あなたはどのくらい不安を感じますか？全く不安を感じな

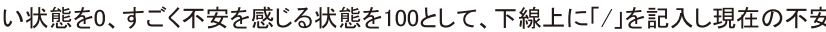
の大きさを示してください。

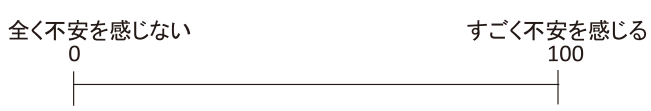

【質問7】機会があれば、また治験に参加したいと思いますか？

(1)〜 (4)の中で、あてはまるもの1つに○をつけ、その理由もお答えください。

(1)是非参加したい (2)どちらかと言えば参加したい

(3)どちらかと言えば参加したくない (4)絶対参加したくない

理由(

【質問8】今後、あなたが知りたいと思う治験の情報は何ですか?あてはまるものに いくつでも○をつけてください。

\begin{tabular}{|c|c|}
\hline $\begin{array}{l}\text { (1)自分が参加した治験の結果 } \\
\text { (3)新薬の開発状況 }\end{array}$ & $\begin{array}{l}\text { (2)実施 (募集) 中の治験や実施している医療機関 } \\
\text { (4)治験に関する法律や制度 }\end{array}$ \\
\hline 他（具 & ) \\
\hline
\end{tabular}

【質問9】「治験」のことをもっと多くの人に知ってもらうには、どのような方法で情報 提供したら良いと思いますか?いくつでも○をつけてください。

(1)セミナーや講演会（2)病院内掲示のポスター（3)病院内設置のリーフレット (4)病院のホームページ（5)新聞や折り込みチラシ（6)テレビ (7)その他 (具体的に

【質問10】その他、ご意見·ご要望等ございましたら、ご記入ください。

【質問11】最後に、集計上、以下の質問にお答えください。

性別 (1)男性 (2)女性

年齢 ( ) 歳

Figure 2 事後調査に用いた質問票

\section{2. 統計解析}

主要評価項目である不安 VAS の変化量は 1 標本 $\mathrm{t}$ 検定 （対応のある $\mathrm{t}$ 検定）により解析した. 副次的評価項目は 5 段階評価を順位尺度 (強く思う：1 point, 少し思う：2 point, どちらとも言えない：3 point, あまり思わない： 4 point, 全 く思わない：5 point）に置換え, Wilcoxon 符号付順位和検 定により解析した。解析ソフトは SPSS（Statistical Package for the Social Sciences) Ver. 22.0 を用いた.

\section{5. 倫理的配慮}

本研究の実施にあたっては，予め当院の臨床研究倫理審 査委員会にて承認を得た.

\section{結＼cjkstart果}

解析対象とその属性を Figure 3 に示す。本研究期間に当 院で実施した治験数は 53 件であり, 155 名の被験者に対し 事前調査の質問票を手交した。そのうち 118 名から回答が 得られた（回収率：76.1\%)。事前調査を完了した 118 名の うち Figure 3 に示す理由により除外した 16 名を除く 102 名の被験者に対して事後調査を行い, 84 名から回答が得ら れた（回収率： $82.4 \%$ )。事前調查および事後調查の双方の 回答が得られ，かつ主要評価項目の解析が可能であったの
は, 治験数 38 件, 被験者数 80 名（男性 44 名, 女性 36 名) であった。その内訳を開発段階別に見ると，第 I 相試験が 1 件 (2 名)，第 II 相試験が 7 件 (11 名)，第 III 相試験が 28 件 (65 名), I / III相試験および II / III 相試験が各 1 件（各 1 名)であった. 試験デザイン別では, 非盲検試験が 13 件 $(24$ 名），二重盲検試験が 25 件（56 名）であった。対照薬の種 別では，プラセボ対照試験が 22 件 (51 名), それ以外のプ ラセボを用いない試験が 16 件（29名）であった。また，疾 患別では悪性腫瘍が 10 件 (23 名), それ以外の慢性疾患が 28 件（57 名）であった。

\section{1. 被験者の意識変化}

\section{1. 治験に対する不安度}

治験に対する不安度の変化を Figure 4 に示す，事前調查 および事後調査における平均不安 VAS（ $\mathrm{mm} \pm \mathrm{SD} ）$ はそれ ぞれ $46.7 \pm 25.9 \mathrm{~mm}, 38.0 \pm 26.4 \mathrm{~mm}$ であり，治験に対す る不安を示す平均 VAS の変化量は $-8.7 \pm 24.7 \mathrm{~mm}$ と有 意 $(P=0.002)$ な低下が認められ，治験を実際に経験する ことで被験者の不安は低減することが明らかとなった。

さらに，治験参加前後において不安 VAS が減少した被 験者（以下，「不安減少群」）は 80 名中 46 名 (57.5\%) で あり，逆に増加した被験者（以下，「不安増加群」）は26名 


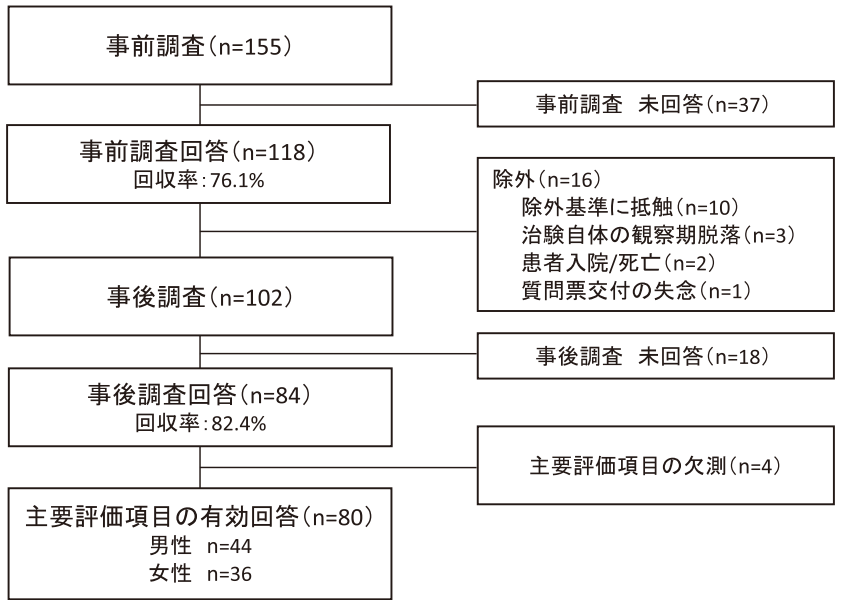

Figure 3 解析対象とその属性

(32.5\%), 変化しなかった被験者は 8 名 $(10.0 \%)$ であっ た.

\section{2. 治験に対する印象度}

治験に対する印象度（全9項目）の変化を Figure 5 に示 す. 9 項目のうち「副作用が心配である $(P=0.005) 」$, 「面 倒・厄介なことである $(P=0.031) 」, 「$ 最新治療が受けられ る $(P=0.033)$, 「治療費が安くなる $(P<0.001) 」$, 「社会

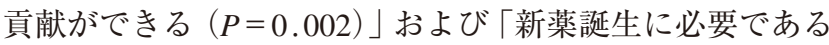
$(P=0.011) 」 96$ 項目は治験参加前後でその印象度が有意 に変化した. 変化の方向は,「副作用が心配である」および 「面倒・厄介なことである」では負の印象が低減する方向へ， 「最新治療が受けられる」,「治療費が安くなる」,「社会貢献 ができる」および「新薬誕生に必要である」では好意的な 印象が是認される方向へ変化した.

\section{3. 治験に対する不安度と印象度との関連性}

治験に対する不安度と印象度との関連性の有無を調べる ため, 不安減少群および不安増加群における印象度の変化 を解析した。

不安減少群では「副作用が心配である $(\mathrm{p}=0.044) 」, 「$ 最 新治療が受けられる $(\mathrm{p}=0.001)$,「治療費が安くなる（p $<0.001) 」$ および「社会貢献ができる $(p=0.010) 」 の 4$ 項 目で治験参加前後における印象度が有意に変化した４項 目の変化の方向は被験者全体における印象変化と同じ方向 であった。一方, 不安増加群ではいずれの項目にも有意な 変化が認められなかった。

また「人体実験である」，「最新治療が受けられる」およ び「実態がよくわからない」の3 項目では不安減少群と不 安増加群とで逆方向に変化する傾向があった．特に「最新 治療が受けられる」の項目ではその変化の違いが顕著であ り，治験が最新治療であることを是認する方向へ変化した 被験者は不安減少群が 46 名中 21 名 $(45.7 \%$ ）であったの に対して, 不安増加群では 26 名中 3 名 (11.5\%)であった。 逆にこれを否定する方向へ変化した被験者は不安減少群で

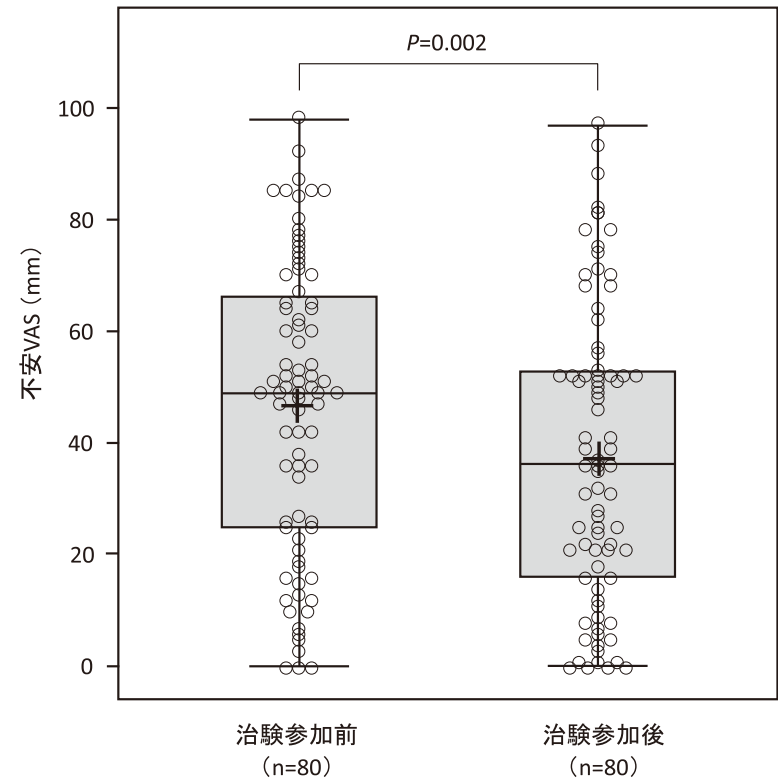

Figure 4 治験参加前後での不安の変化 +は平均值を示し，検定は対応のある $\mathrm{t}$ 検定を用いた. 箱の下端，中央，上端は，それぞれ 25 パーセンタイル值，中央 值， 75 パーセンタイル值を示す.

ひげの上端，下端はそれぞれ最大值，最小值を示す．

は 46 名中 4 名 $(8.7 \%)$ であったのに対して, 不安増加群 では 26 名中 7 名 $(26.9 \%)$ であった.

\section{2. 事前調査における治験に対する認知および参加動機}

\section{1. 治験の認知度}

事前調查（Figure 1) において治験参加以前の「治験」の 認知度について尋ねたところ, 108 名のうち 21 名 (19.4\%) は「言葉と内容を知っている」とした。一方，「言葉は知っ ているが内容は知らない」拈よび「言葉も内容も知らない」 はそれぞれ 33 名 $(30.6 \%), 52$ 名 $(48.1 \%)$ であり, 無回 答は 2 名（1.9\%）であった。また「治験が新薬誕生に必 要である」の項目については, これを認識していた被験者 は 50 名 $(46.3 \%)$, 認識していなかった被験者は 57 名 （52.8\%）であり，無回答は 1 名（0.9\%）であった.

\section{2. 治験参加の動機}

治験参加の動機を Figure 6 に示す，選択肢のうち回答を いくつでも選択可能とした場合（複数選択）の治験への参 加理由は，「治験薬の効果を期待するから」が $89.8 \%$ と最 も多く，次に「病気（治療）に対して前向きになりたいか ら」が $61.1 \%$,「新薬開発・医学の進歩に貢献できるから」

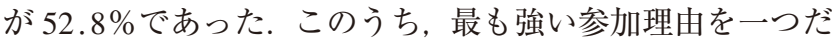
け選択してもらった場合（単一選択）は，「治験薬の効果を 期待するから」が $41.7 \%$, 「病気（治療）に対して前向きに なりたいから」および「担当医師が勧めたから」がそれぞ れ $14.8 \%$ および $13.9 \%$ であった。 


\begin{tabular}{|c|c|c|c|c|}
\hline 事前調査 & 21.4 & 56.0 & & 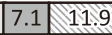 \\
\hline 事後調査 & 17.9 & 47.6 & 9.5 & 179 \\
\hline
\end{tabular}

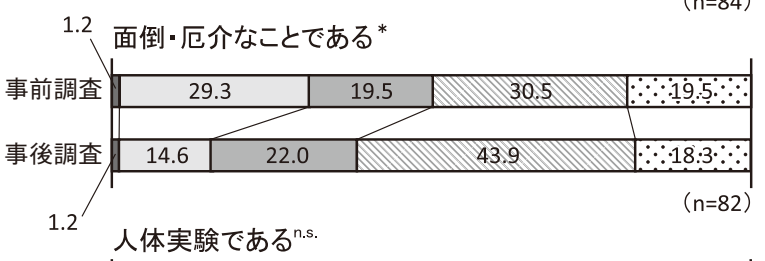

\begin{tabular}{|c|c|c|c|c|c|}
\hline 事前調査 & \begin{tabular}{|l|}
11.1 \\
\end{tabular} & 39.5 & 13.6 & 22.2 & $1: 3: 6$ \\
\hline 事後調査 & \begin{tabular}{|l|}
6.2 \\
\end{tabular} & 37.0 & 19.8 & 19.8 & $173:$ \\
\hline
\end{tabular}
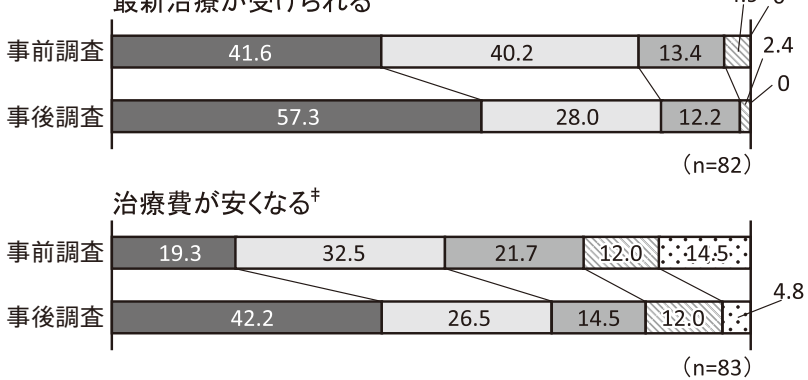

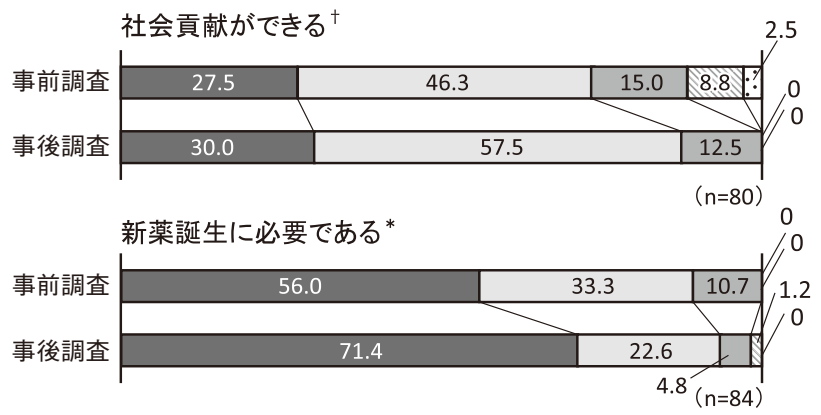

2.5 実態がよくわからない..
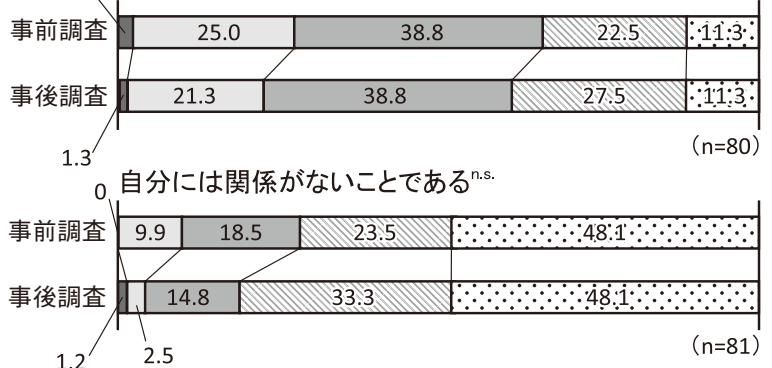

$\square$ 強〈思う $\square$ 少し思う $\square$ どちらとも言えない あまり思わない $\because$ 全く思わない

Figure 5 治験に対する印象変化（\%)

事前調查と事後調查での治験に対する印象度の比較, $*: P<0.05 \quad \dagger: P<0.01 \quad$ \$ $: P<0.001 \quad \mathrm{n}$. s. : not significant 各項目の $\mathrm{n}$ は事前調査と事後調査の両方の有効回答が得られた被験者数である.

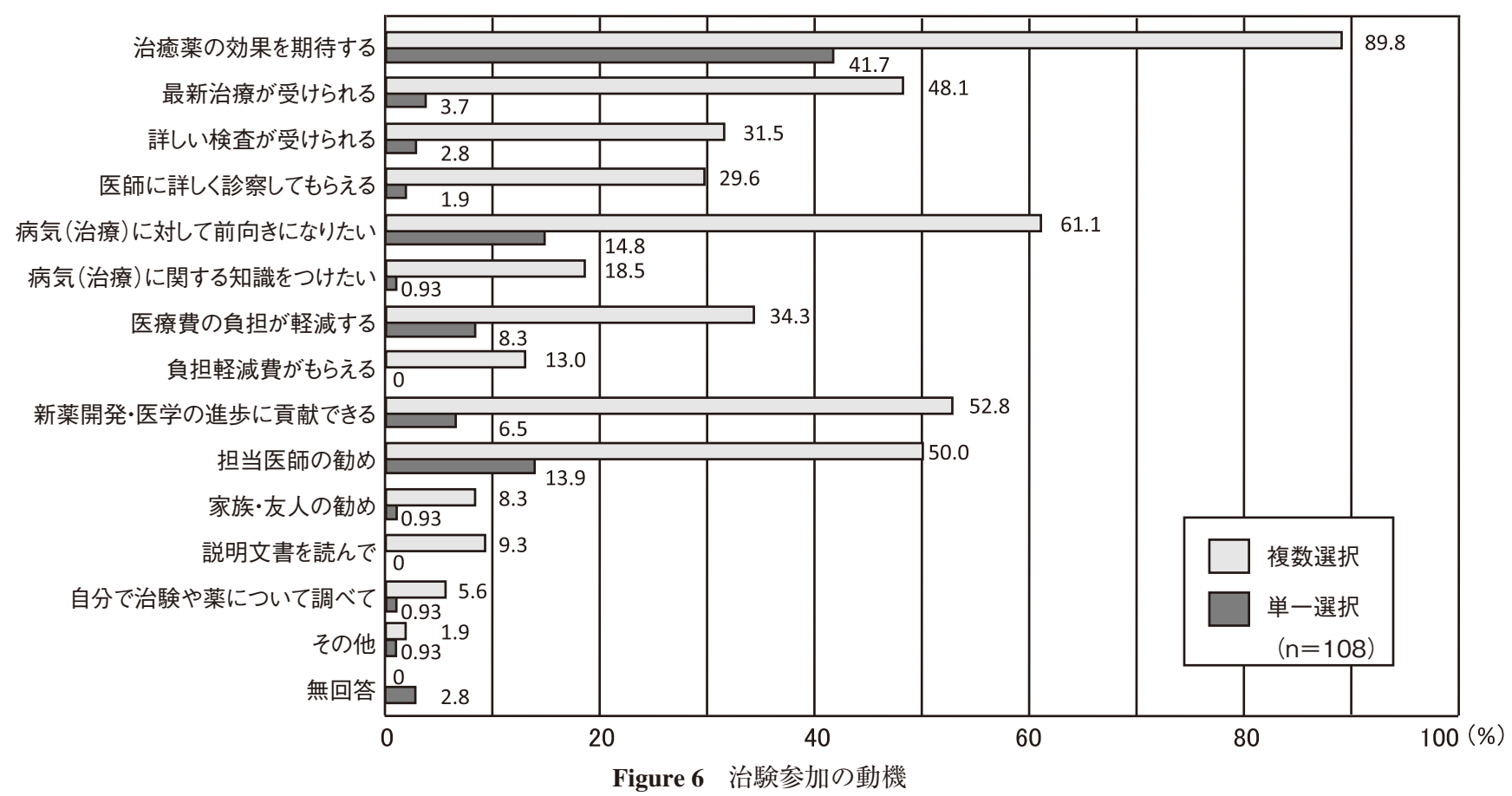


A)治験に参加して良かったと思うこと

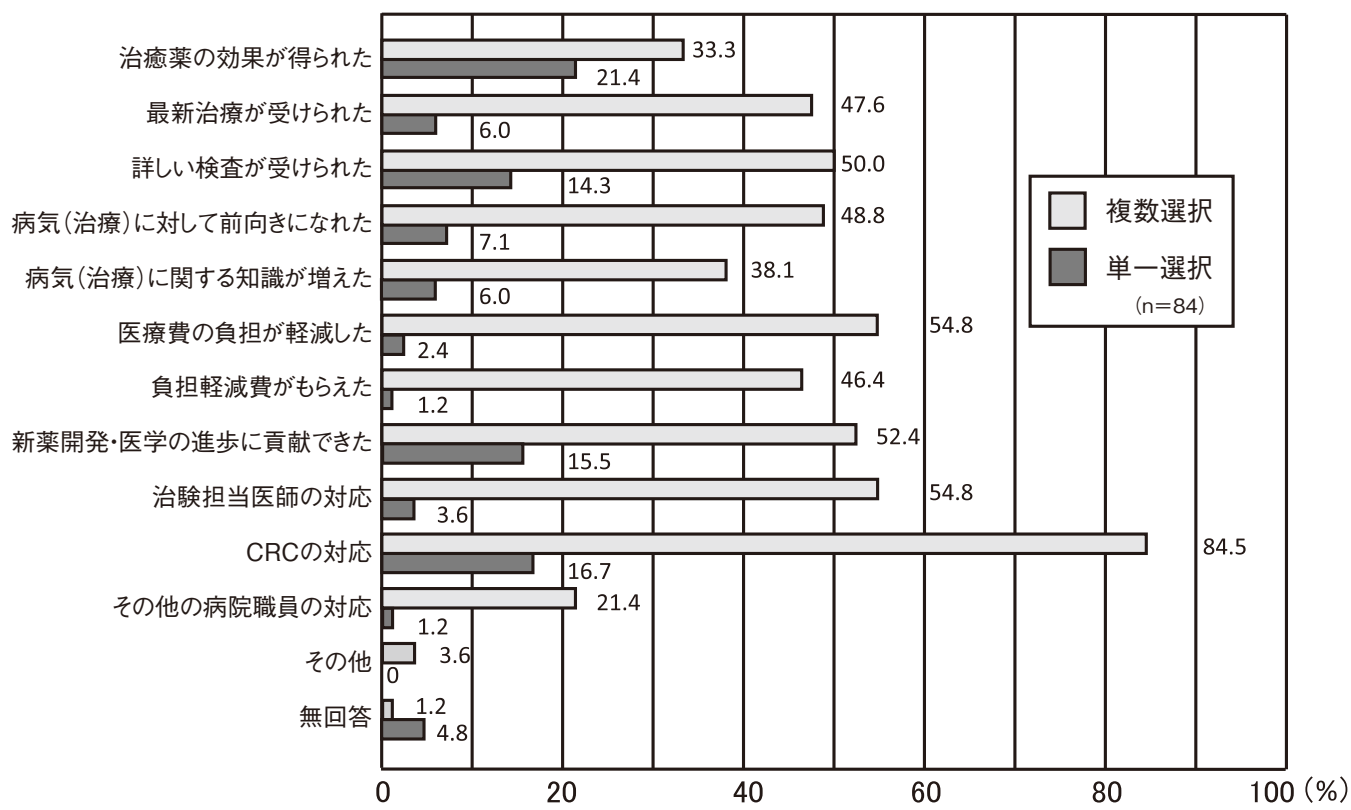

B) 治験に参加して悪かったと思うこと

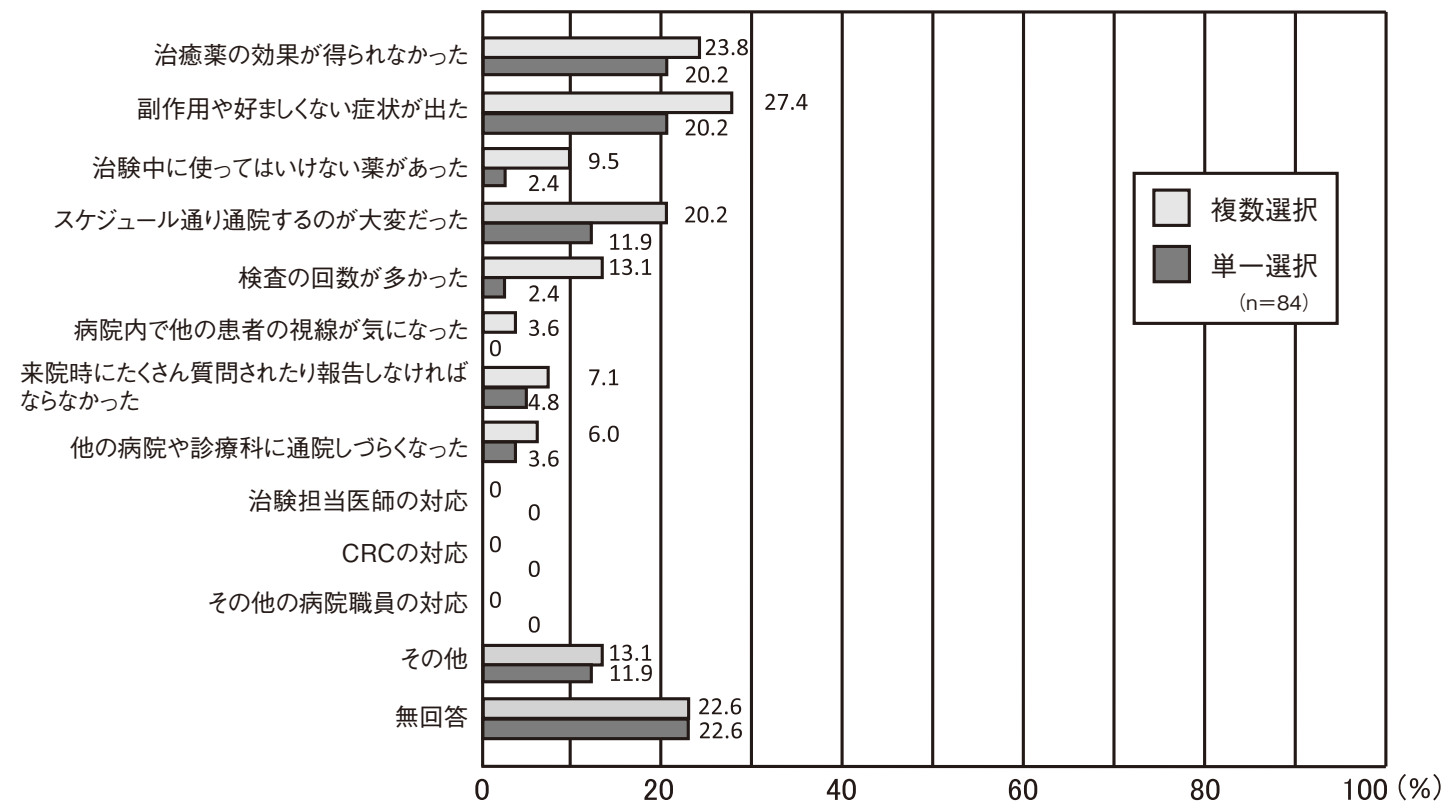

Figure 7 治験に対する評価

事後調査において，治験にして良かったと思うこと（A）および悪かったと思うこと（B）について各々複数 選択および単一選択にて回答を得た。

\section{3 . 事後調査における治験に対する評価および今後の参加意向}

\section{1. 治験に対する評価}

治験に対する評価を Figure 7 に示す.「治験に参加して 良かったと思うこと」の複数選択による評価では,「CRC の対応」が $84.5 \%$ と最も多く, 次に「医療費の負担が軽減 した」および「治験担当医師の対応」が共に $54.8 \%$ あ゙あ た，単一選択による最も良い評価は，「治験薬の効果が得ら れた（以下，「効果発現」)」が $21.4 \%$ であた（Figure 7A）.
一方，「治験に参加して悪かったと思うこと」の複数選択 による評価では,「副作用や好ましくない症状が出た(以下， $\lceil$ Adverse Event ; AE の発現」)」が $27.4 \%$ と最も多く, 次に 「治験薬の効果が得られなかった（以下，「効果不発揮」）」 が $23.8 \%$ であった。単一選択による最も悪い評価は,「効 果不発揮」および「AEの発現」が共に $20.2 \%$ あった (Figure 7B).

さらにこの結果を不安減少群と不安増加群とに層別解析 
Table 1 治験に対する評価（回答数上位 3 項目）

\begin{tabular}{|c|c|c|c|c|c|c|c|c|}
\hline & \multicolumn{4}{|c|}{ 治験に参加して良かったと思うこと } & \multicolumn{4}{|c|}{ 治験に参加して悪かったと思うこと } \\
\hline & \multicolumn{2}{|c|}{ 複数選択 } & \multicolumn{2}{|c|}{ 単一選択 } & \multicolumn{2}{|c|}{ 複数選択 } & \multicolumn{2}{|c|}{ 単一選択 } \\
\hline \multirow{4}{*}{$\begin{array}{c}\text { 不安減少群 } \\
(\mathrm{n}=46)\end{array}$} & CRC の対応 & $38(82.6 \%)$ & 効果発現 & $10(21.7 \%)$ & \multirow{4}{*}{$\begin{array}{l}\mathrm{AE} \text { の発現 } \\
\text { スケジュール } \\
\text { による制約 } \\
\text { 効果不発揮 }\end{array}$} & \multirow{4}{*}{$\begin{array}{rr}11 & (23 \\
8 & (17 \\
6 & (13\end{array}$} & \multirow{4}{*}{$\begin{array}{l}\mathrm{AE} の \text { 発現 } \\
\text { スケジュール } \\
\text { による制約 } \\
\text { 効果不発揮 }\end{array}$} & \multirow{4}{*}{$\begin{array}{r}10(21.8 \%) \\
6(13.0 \%) \\
5(10.9 \%)\end{array}$} \\
\hline & 最新治療 & $26(56.5 \%)$ & $\mathrm{CRC}$ の対応 & $9(19.6 \%)$ & & & & \\
\hline & 治療に前向き & $25(54.3 \%)$ & 詳しい検査 & $7(15.2 \%)$ & & & & \\
\hline & $\begin{array}{l}\text { 治験担当医の } \\
\text { 対応 }\end{array}$ & $25(54.3 \%)$ & & & & & & \\
\hline \multirow{5}{*}{$\begin{array}{c}\text { 不安増加群 } \\
(\mathrm{n}=26)\end{array}$} & $\mathrm{CRC}$ の対応 & $23(88.5 \%)$ & 効果発現 & $5(19.2 \%)$ & $\mathrm{AE}$ の発現 & $23(88.5 \%)$ & 効果不発揮 & $11(42.3 \%)$ \\
\hline & 負担軽減費 & $15(57.7 \%)$ & 詳しい検査 & $5(19.2 \%)$ & \multirow{4}{*}{\multicolumn{2}{|c|}{$\begin{array}{lll}\text { 効果不発揮 } & 20 & (76.9 \%) \\
\text { スケジュール } & & \\
\text { による制約 } & 17 & (65.4 \%) \\
\text { に }\end{array}$}} & \multirow{4}{*}{\multicolumn{2}{|c|}{$\begin{array}{ll}\mathrm{AE} \text { の発現 } & 4(15.4 \%) \\
\text { スケジュール } & 3(11.5 \%) \\
\text { による制約 } & 3\end{array}$}} \\
\hline & 詳しい検査 & $14(53.8 \%)$ & $\mathrm{CRC}$ の対応 & $4(15.4 \%)$ & & & & \\
\hline & & & 開発に貢献 & $4(15.4 \%)$ & & & & \\
\hline & & & 病気の知識 & $4(15.4 \%)$ & & & & \\
\hline
\end{tabular}

した（Table 1).「治験に参加して良かったと思うこと」の 複数選択では, 不安減少群で「CRCの対応」が $82.6 \%$ と最 も多く, 次に「最新治療が受けられた」が $56.5 \%$ あった。. 不安増加群では「CRCの対応」が $88.5 \%$ と最も多く, 次に 「負担軽減費がもらえた」が $57.7 \%$ あった。単一選択で は, 不安減少群で「効果発現」が $21.7 \%$ と最も多く, 不安 増加群では「効果発現」および「詳しい検査が受けられた」 が共に $19.2 \%$ であった。

一方,「治験に参加して悪かったと思うこと」の複数選択 では, 不安減少群で「AEの発現」が $23.9 \%$ と最も多く, 次 に「スケジュール通りに通院するのが大変だった（以下， 「スケジュールによる制約」)」が $17.4 \%$ であった。不安増 加群では「 $\mathrm{AE}$ の発現」が $88.5 \%$ と最も多く, 次に「効果不 発揮」が76.9\%であった. 単一選択では, 不安減少群で「AE の発現」が $21.8 \%$ と最も多く, 不安増加群では「効果不発 揮」が $42.3 \%$ であった。

\section{2. 治験参加による不安感の定性的調査}

治験に対する不安度はVASによる定量的な測定のほか に, 定性的な評価も行った. 84 名のうち, 参加後に不安感 は「減少した」が 27 名 (32.1\%), 「不変」が 25 名 $(29.8 \%)$, 「増加した」が 13 名 (15.5\%), 「参加前から不安はなかっ た」および「無回答」がそれぞれ 10 名 $(11.9 \%)$ および 9 名（10.7\%）であった。不安感が減少した理由としては, 「治験薬の効果発現」,「CRCの対応」および「病状の変化」 がそれぞれ $29.6 \%$ ，22.2\%および $22.2 \%$ と上位を占めた。 一方, 不安感が増加した理由の上位は「治験薬の効果不発 揮」,「病状の変化」および「AEの発現」がそれぞれ $38.5 \%$, $38.5 \%$ および $23.1 \%$ であった。

\section{3. 今後の治験参加意向}

今後の治験参加意向は, 84 名のうち「(機会があれば) 是 非参加したい」が 23 名 $(27.4 \%)$ ，「どちらかと言えば参加 したい」が 44 名 $(52.4 \%)$ であり, 被験者 67 名 $(79.8 \%)$
が今後の参加意向を示した，逆に，「どちらかと言えば参加 したくない」および「絶対に参加したくない」の否定的な 意見はそれぞれ $15.5 \%$ および $0 \%$ であった.

\section{4. 治験に関する情報}

治験に関して入手したい主な情報（複数選択）は，84名 のうち「自分が参加した治験の結果」が 73 名 (86.9\%), 「新薬の開発状況」が 56 名 $(66.7 \%)$ であった。 その入手 方法は医療機関における「ポスター掲示」および「リーフ レット」が共に $53.6 \%$ であり, 次に「ホームページ」,「テ レビ」および「新聞や折り込みチラシ」等のマスメディア がそれぞれ 39.2\%，34.5\%および $31.0 \%$ お゙あった。また， セミナーや講演会は $28.6 \%$ であった.

\section{考察}

治験参加者を対象とした意識調査は我々が過去に行った ものも含めて多数報告されている ${ }^{1 \sim 4,6)}$. しかし，これらの 報告は治験参加中または終了後に実施されており，治験を 経験したことによる振返りの感想を把握するだけの定性的 な調査であった。そのため, 治験参加者意識の経時的変化 やそれに関連する要因までは言及していない。治験が患者 の協力なくして成立しない以上，参加者の多様な心証を把 握することは治験を推進する観点からも非常に重要なこと と思われる。本研究は被験者の不安度を評価するための指 標としてVAS を用い, 治験参加前後の各調查時点におけ る被験者の意識を数值化することにより経時的な変化を定 量的に捉えた。

過去に行われた調査では，一般の人が治験に参加したく ない理由の第 1 位として 6 割以上が治験に対する不安感を 挙げている ${ }^{5)}$. 今回我々が行った事前調査の段階でも不安 感が全くないとした被験者の割合は僅か $3.8 \%$ と少数であ り，多くの被験者が程度の差はあるものの何らかの不安感 を有していることが明らかとなった。今回の研究では治験 
に対する不安度を主要評価項目に設定し，変化量を測定し た. その結果, 不安度を示す平均 VAS は治験経験後に不安 軽減の方向へ有意に変化したが，その一方で不安が増加し た被験者も約 3 割存在することが明らかとなった.

治験に対する印象の変化は, 9 項目のうち 6 項目の印象 度が有意に変化した（Figure 5)。いずれの項目も治験に対 する負の印象が低減, あるいは治験に対して好意的な印象 を持つ方向へとシフトし, 中でも「治療費が安くなる $(P<$ 0.001)」は最も著しい変化が認められた，事前調查では治 験参加の動機として「医療費の負担が軽減するから」を選 択した被験者の割合が $34.3 \%$ あったた。過去の調査 ${ }^{4,6,7)}$ で は治療費の軽減については被験者がさほど重要視していな いと報告していたが, 治験参加後に治療費の軽減を高評価 した被験者は全体で $54.8 \%$ と高率であり, 被験者の不安に は疾患や治療そのものに対する不安だけでなく, 経済的な 不安も内包されている可能性が考えられる。 また, 不安減 少群と不安増加群とのサブ解析では 3 項目に逆方向の印象 の変化が認められた. 不安増加群はいずれの項目も治験に 対する印象が負の方向へ移動し，特に「最新治療が受けら れる」の項目は不安減少群と比較してその印象度が著しく 乘離していた，患者にとって治験参加を決断する際に最も 重要視することは, 最新治療として期待される治験が疾病 の治癒・寛解をもたらすことである。これは事前調查によ る治験への参加動機として $89.8 \%$ の被験者が「治験薬の効 果を期待するから」を選択したことからも明らかであり， 被験者の多くはさまざまな不安要素を抱えながら治験薬の 効果発現を期待して治験に参加している。しかし，この期 待感に真っ向から反する「効果不発揮」は心理的な落胆を 招いて不安感を増幅し, さらには治験に対する印象度を負 の方向へ変化させる主な要因になり得たと推測される.

事後調查で行った治験全般に関する被験者の定性的評価 では,「治験に参加して良かったと思うこと」の単一選択で 最も多かったのは「効果発現」の項目であった (Figure 7A). これは治験参加の動機の回答結果からしても当然と思われ る。また，「CRCの対応」については不安減少群および不 安増加群の両群共に非常に高い評価をしており, CRC は 治験には欠くことのできない存在であることが改めて確認 できた（Table 1).

「治験に参加して悪かったと思うこと」の複数選択では $\lceil\mathrm{AE}$ の発現」が最も多く, 単一選択では「効果不発揮」と $「 \mathrm{AE}$ の発現」が同率であった (Figure 7B). 被験者個々にお ける治験薬の効果や副作用あるいは $\mathrm{AE}$ の有無は予め予測 することが困難であり，これらの原因による不安感の増幅 を完全に回避することはできない．

一方で, 治験スケジュールは予め実施計画書に規定され ており, $\mathrm{AE}$ のように予測不可能でもなく, 被験者個々に よって条件が異なるわけでもない．治験担当医師や CRC はこれを遵守する必要性を十分説明しており, 参加に同意
した時点で被験者の理解が得られているものと認識してい た.しかし，「治験に参加して悪かったと思うこと」として 不安減少群抒よび不安増加群共に「スケジュールによる制 約」を選択した人が多かったことから，被験者は実施者側 が想像する以上に治験スケジュールによる拘束感を強く感 じていると考えられた。この背景として，解析対象となっ た被験者の約 7 割が慢性疾患の患者であり，通常診療であ れば数力月に 1 回の来院であるにもかかわらず，治験参加 により頻回な来院を求められたことが挙げられる。このこ とが,「スケジュール通りに通院するのが大変だった」との 評価に繋がり, 治験の印象を悪くしたと思われる。これは, 被験者が次回の治験参加を躊躇する原因となり, その結果, 治験の推進を妨げる要因の一つになり得ると考えられる

\section{(Table 1).}

今回の結果から，実施者側は十分に説明していると考え ていた事項であっても，被験者にとっては未だ不十分な状 態であることも明らかとなった．これは我々も十分に反省 すべき点であり，今後の業務を行ううえで留意すべき重要 な事柄と言える。一方，治験を計画する者は，評価項目を 必要最小限に設定し, 被験者に過度な負担を与えないこと が治験の進渉等に好影響をもたらすのではないかと考え る.

本研究では治験に対する認知度, 必要性および今後の参 加意向についての定性的調查も行った. 治験の認知度につ いては日本製薬工業協会が一般人を対象にアンケート調査 を行っており，直近の結果では $80 \%$ 以上が治験を「よく 知っている」あるいは「ある程度知っている」としている5 しかし, 今回の結果は他の報告 ${ }^{2,45}$ に比べて治験に対する 認知度が低く $50.0 \%$ でった．また，治験の必要性につい ても同様の傾向が見られた。これは，日本製薬工業協会の アンケート調查が首都圈・京阪神圈で行ったのに対し, 本 研究は地方都市在住者が対象となったことによる地域差が 影響した可能性も考えられる。

治験参加の動機は「治験薬の効果を期待するから」が 89.8\%と最も多く，ほとんどの被験者が治験薬の効果を希 求していることが明らかとなった（Figure 6). また，次回 の治験参加意向では回答者の $79.8 \%$ が「是非参加したい」 あるいは「どちらかと言えば参加したい」としており，否 定的な意見は少数であった。

被験者の多くが治験薬の効果発現への期待感，通常診療 と異なる治療・検查および未知なる治験自体への漠然とし た不安感等さまざまな要素を抱えながら治験に参加してい る. 本研究によりこれら被験者の内包する期待感と不安感 を幾分明らかにできたのではないかと考える。しかしなが ら, 被験者心理に影響を与える要因としては, 本研究にて 推察された因子以外にも, 被験薬または対照薬の種類, 開 発段階および試験デザイン等の治験自体の特性や，疾患の 種類, 治療歴, 被験者個人の理解度抒よび治験参加に至っ 
た経緯等の被験者背景も関与すると考えられる.今回はこ れらの要因と被験者心理との相関性が解析可能となる症例 数を集積することができなかったが，今後これらを検証す る研究の必要性を感じた。なお, 本研究は質問票への回答 を応諾した人のみから収集しており，得られた結果は必ず しも被験者全体の意見を反映しているとは言えない。実際 に事前調查の協力は得られたが事後調査では回答を拒否さ れ，協力を得られなかった被験者もいた，これはアンケー 卜を用いた研究の限界であり, 今回の結果は被験者全員の 意見が十分に反映された訳でないことに留意する必要があ る.

\section{結 論}

本研究により, 被験者の治験に対する不安度は治験参加 後に有意に低減し, 印象度も好転化することが明らかと なった．また，この変化に影響を与えた一部因子を解明す ることができ, 本研究で得られた結果は効果的な被験者対 応を模索するうえで一助になると考えられる。

しかし, 本研究では被験者意識に関連すると思われる全 ての因子について検討していないため, 今後, 今回は検討 に至らなかったその他の因子との関連性を究明していきた い.また, CRC は被験者にとって不可欠な存在であること を認識し, 被験者の心身の負担に配慮すると共に, 被験者 に過度の負担を生じさせない方策を治験依頼者に対して提 言することで, 治験の啓発および推進に貢献したい.

\section{資金源の公開}

本研究に対しては外部支援を受けていない.

\section{Conflict of Interest}

全著者において, 本研究に関し開示すべき利益相反はない.

\section{謝辞}

本研究の実施にあたり，質問票の回答にご協力いただきま した被験者の方拉よび本研究に協力いただきました三重野牧 子先生, 当院 CRC の服部由, 菊池明子, 若松朋恵, 小川仁子, 大木加奈子, 大島悟, 澤口武尊, 金子朋香, 齋藤こずえ, 石山 裕美, 前田由利子, 石川真由美, 奥畑啓江, 坂田友里子, 古田 好美（敬称略）に心より深謝いたします。

\section{文 献}

1）小嶋亜純, 服部由, 鈴木久仁子, 大島悟, 石川真由美, 石山裕美 ほか. 被験者の治験に関する意識調查について. 臨床薬理. 2010； 41(Suppl) : S295.

2）小林真一, 和泉啓司郎, 川崎敬子, 清水昭, 辻本好子, 平山佳伸 ほか. 治験に関する啓発活動等の現状に関する調查班報告書. 平 成 18 年 10 月.

[http://www.jmacct.med.or.jp/plan/files/jiki/3-3keihatsu_2.pdf (accessed 2015-06-27) ]

3）植山茂宏, 森千鶴, 岩田洋子, 小野美和子, 植山朋代. 小児臨床 試験に参加した患児保護者の心理に関するアンケート調查．臨 床薬理. $2012 ； \mathbf{4 3}(2) ： 65-72$. doi ：org/10.3999/jscpt.43.65.

4）宮田か抢る, 佐藤恵子. 治験参加者の治験に対する意識調查 治験参加に影響する要因. 臨床薬理. $2014 ; 45(1) ： 11-15$. doi : org/10.3999/jscpt.45.11.

5）日本製薬工業協会. 第 9 回くすりと製薬産業に関する生活者意 識調查. 調查結果報告書. 2015 年 7 月 : 66-68, 71-76.

6）古川裕之, 北川明, 工藤正純, 中尾泰史, 手島みどり, 山口辰哉 ほか，被験者の治験に対する意識に関する多施設共同調査の試 み. 臨床薬理. $2001 ； 32(1) ： 183 \mathrm{~S}-184 \mathrm{~S}$.

7）小菅和仁, 鈴木真紀, 渡邊裕司, 橋本久邦, 大橋京一. 外来患者 に扔ける治験に関する意識調查. 臨床薬理. $2001 ； 32(1) ： 177 S^{-}$ $178 \mathrm{~S}$. 